\title{
Academics job satisfaction and job stress across countries in the changing academic environments
}

\author{
Jung Cheol Shin · Jisun Jung
}

Published online: 28 September 2013

(C) The Author(s) 2013. This article is published with open access at Springerlink.com

\begin{abstract}
This study examined job satisfaction and job stress across 19 higher education systems. We classified the 19 countries according to their job satisfaction and job stress and applied regression analysis to test whether new public management has impacts on either or both job satisfaction and job stress. According to this study, strong market driven countries are in the high stress group and European countries are in the high satisfaction group. The classification implies that market oriented managerial reforms are the main source of academic stress while the high social reputation of academics in their society and academic autonomy are the source of job satisfaction. Our regression analysis also shows that the new public management which is measured by the performance-based management in this study is the main source of academic job stress. In addition, this study highlighted the higher education systems that are classified as the high satisfaction and high stress group. These countries represent the conflicting nature of current academic society — on the one hand they are satisfied, but on the other they are highly stressful.
\end{abstract}

Keywords Job satisfaction - Job stress $\cdot$ New public management $\cdot$ Academic profession $\cdot$ Changing academic environment

\section{Introduction}

Academic work environments have deteriorated since the 1980s (e.g., Harman 2001; Kinman and Jones 2008; Houston et al. 2006; Tytherleigh et al. 2005). Faculty workloads

J. C. Shin (西)

Department of Education, Seoul National University, Kwanak-gu, Seoul 151-742, South Korea e-mail: jcs6205@snu.ac.kr

\section{J. Jung}

Division of Policy, Administration and Social Sciences Education, Faculty of Education, The University of Hong Kong, Pokfulam Road, Hong Kong, SAR, China

e-mail: jisun@hku.hk 
are increasing and the balance between academic work and family life has become a critical issue (e.g., Hendel and Horn 2008; Kinman and Jones 2008; Olsen 1993). In addition, managerial work has increased in recent years with managerial reforms such as the new public management that accompanies performance-based management, budget short-cuts, and efficiency-oriented management (e.g., Fredman and Doughney 2012; Houston et al. 2006). On the other hand, academics are paid relatively less than other professions (e.g., Fredman and Doughney 2012; Lyons and Ingersoll 2010: Waitere et al. 2011). Bryson (2004), Locke and Bennion (2013) refer to the deteriorating work environment as academic proletarianisation.

Nevertheless, national studies of academic work show that academics are satisfied with their job (e.g., Harman 2001, 2003; Houston et al. 2006). The controversial perspectives on academic work are explained by two different dimensions of intrinsic motivation and external work conditions, borrowing a theoretical concept from Herzberg et al.'s (1959) motivational and hygiene factors (Houston et al. 2006; Halsey 1992; Lacy and Sheehan 1997). According to these studies, intrinsic motivation is related to the job itself and is a cause of job satisfaction. On the other hand, work conditions are related to the work environment, which can be a cause of job dissatisfaction. National surveys mentioned above also show the duality of job satisfaction and job stress-academics are satisfied with their job, but at the same time they feel stressed. These studies explain the nature of the academic job where academics are satisfied with the job itself but, their work environments are getting less favorable under the managerial reforms (e.g., Fredman and Doughney 2012; Houston et al. 2006; Winefield et al. 2003).

The levels of job satisfaction and job stress differ across higher education systems. According to Bentley et al. (2013), Japanese academics, for example, feel highly satisfied with their job, but are highly stressed at the same time. This is different for UK and Australian academics who are relatively less satisfied, and highly stressed. There might be systemic similarities and/or difference across systems. Each system has their own way of defining academic jobs, workloads, the relative weight between teaching and research, salary and rewards (Clark 1983; Cummings and Shin 2013). In addition, managerial reforms, which have a strong influence on academic life, are adopted and implemented differently in each country (Locke et al. 2011). As Tytherleigh et al. (2005) discussed, most job satisfaction and job stress studies are conducted in the Anglo-American countries, where the managerial reforms are actively adopted. Because of the different contexts and different degrees of managerial reforms, academic job satisfaction and job stress differ across countries.

Considering the systemic differences across countries, one primary research enquiry is which system shares similarities with others in terms of job satisfaction and job stress. This requires comparative studies on academic job satisfaction and job stress. However, very few studies have been conducted on the thematic issues from a comparative perspective. One difficulty in conducting a comparative study is that there is little comparable data from international comparative studies of academic profession. There are two well known international comparative surveys - the Carnegie Survey on Academic Profession in 1992 led by the Carnegie Foundation and the changing academic profession (CAP) survey 2007-2008 led by international comparative research teams. Both surveys provide comparable data for satisfaction and job stress. Lacy and Sheehan (1997) and Enders and Teichler (1997) have discussed how job satisfaction differs across countries based on Carnegie survey data of 1992, and Bentley et al. (2013) also led academic discussion on the job satisfaction based on the CAP data.

The previous comparative studies contributed to our understanding of academic job satisfaction and job stress from a comparative perspective. These studies report descriptive 
differences across countries (Enders and Teichler 1997) and/or further developed academic discussion by applying multivariate analysis to investigate the determinants of job satisfaction (Lacy and Sheehan 1997; Bentley et al. 2013). However, these studies did not pay much attention to the systemic similarities or differences across countries. In addition, these studies did not pay much attention to the possible association between managerial reforms and job satisfaction in their analysis while managerial reforms are frequently discussed in job satisfaction and jobs stress studies (e.g., Harman 2001; Houston et al. 2006; Tytherleigh et al. 2005). By contrast, this study investigates how job satisfaction and job stress are similar or differ across higher education systems, and analyze whether job satisfaction and job stress are related to managerial reforms.

\section{Job satisfaction and job stress in changing academic environments}

Job satisfaction and job stress

Since Herzberg et al.'s (1959) theory was proposed, many scholars have considered the duality of motivators and hygiene factors. Some studies have reached at similar conclusion as Herzberg, while others have drawn different conclusions. For example, Halsey (1992) and Hill (1986) have found that intrinsic motivators are critical for job satisfaction, but not the extrinsic factors. Others (e.g., Gillespie et al. 2001; Tytherleigh et al. 2005) found that factors related to work conditions such as job security, resources, workloads, reward and recognitions are critical as well as intrinsic factors for job satisfaction. When the work conditions were better than they are currently, academics' job satisfaction might be mainly related to motivators; however, work conditions became critical factors as well as motivators in determining job satisfaction in the current work environment where work conditions such as salary and rewards deteriorated compared to other jobs as discussed by Bryson (2004) and Parker and Jary (1995). As McInnes (2000) argued, the syntheses of different perspectives explain current job satisfaction.

Reflecting the changing academic work environments, many recent studies consider both factors explain job satisfaction rather than clear distinctions between intrinsic or extrinsic factors. Examples are Bryson (2004), Winer and Sarros (2002), and Houston et al. (2006). Researchers are more interested in whether job satisfaction is increasing or decreasing in current academic environments, especially under the managerial reforms. Since the 1990s growing numbers of studies have focused on declining job satisfaction and its causes because academic work conditions are declining. For example, Harman's (2001) study which is based on Australian data from two time points - 1977 and 1997_found that academics were relatively highly satisfied with their job although academic work conditions had declined. However, recent literature reports that job satisfaction is declining in many countries (e.g., Bryson 2004; Houston et al. 2006).

In addition, recent studies pay attention to both job satisfaction and job stress at the same time because job stress is related to faculty turn over, their performance, and their commitment to their organization (e.g., Catano et al. 2010; Gillespie et al. 2001; Ryan et al. 2012; Tytherleigh et al. 2005; Winefield et al. 2003). An example is the study by Olsen (1993) who modeled job satisfaction and job stress in the same analytical model. Olsen grouped 18 items related to job satisfaction and job stress into four variables-compensation and security, recognition, conflict, and inner rewards-instead of intrinsic and extrinsic factors. Olsen's study and follow up studies (e.g., Houston et al. 2006; Olsen et al. 1995 ) found that academic job satisfaction is also influenced by work conditions and job 
stress is determined by the weak internal motivators such as reduced academic autonomy under managerial reforms (e.g., Fredman and Doughney 2012). These studies imply that both intrinsic and extrinsic factors affect job satisfaction and job stress at the same time.

Academic jobs across higher education systems

Academic's role in the higher education systems, their participation in decision making processes within their university, their social reputation, and evaluation and rewards differ across systems. The systemic differences in higher education have been proposed and discussed by higher education scholars including Ben-David (1977), Clark (1983), and Cummings (2004). Most of these academic discussions focus on the original model of modern university systems in the developed countries such as Germany, France, the UK, the USA, and Japan. Among these academic discussions, Clark's conceptualization of systemic differences across countries are frequently cited in higher education research, especially his three types of coordination by market, state, and academic oligarchy. The coordination types have implications for understanding academic jobs as well as governance in contemporary higher education. In the countries that have strong professororiented traditions, academics hold strong influence in academic decision making while the state has a strong influence in the state-oriented countries, and the market principle in market-oriented countries.

In professor-oriented systems, mostly in many European systems, where academics are deeply involved in decision making in academic affairs, their social reputation is higher than in state oriented or market oriented systems (e.g., Ben-David 1977; Clark 1983). Also, accountability is more aligned with internal accountability in the professor-oriented system where accountability is based on a professor's specialty (Romzek 2000). In the systems, academics have greater freedom in defining their jobs and also their specialty is more respected within and outside of academia. On the other hand, in the market-oriented systems, mostly in the Anglo-American systems, an academic's social reputation is relatively lower than in professor-oriented systems (e.g., Clark 1983; Teichler 2007), and public accountability aligns more with external accountability where external stake holders are involved in the accountability processes (Romzek 2000). In this system, academic jobs are defined by market and external stake holders, so that academics are relatively less empowered than their peers in the professor-oriented systems. In the state-oriented systems, academics are deeply controlled by their states and their autonomy is not highly respected by states.

Although Clark's typology does not fully explain the systemic differences across countries, it has implications for understanding how each system differs from others including job satisfaction and job stress across countries (Cummings and Shin 2013). For example, job satisfaction and job stress are closely related to who defines academics' jobs and how much autonomy they have. According to Clark's work and the literature on job satisfaction and job stress, academics in the professor-oriented systems might be more satisfied than their colleagues in the market oriented systems (e.g., Bentley et al. 2013). On the other hand, academics in the professor-oriented systems might be less stressed than their colleagues in the market-oriented systems. This has been supported by research where academics in the market-oriented systems show low satisfaction and high stress (e.g., Bentley et al. 2013). Their job security in the market-oriented systems is relatively weaker than in the professor-oriented systems. Nevertheless, these systemic differences between types are relative terms and should be more carefully discussed with empirical data. 
Managerial reforms and job stress

The typology of higher education systems explains the difference of job satisfaction and job stress across countries to some extent-academics are more satisfied when they are more autonomous and academic accountability is based on their professional specialty rather than relying on outside stake holders (e.g., Bryson 2004). However, many higher education systems have adopted private corporation style of management (e.g., Anderson 2008). Although academics are relatively autonomous in academic affairs, external stakeholders have become deeply involved in university affairs under the name of accountability (e.g., Taylor 2012). The new accountability systems replace government regulations through performance indicators, quality assurance, and performance-based funding mechanisms (e.g., Anderson 2008; Bryson 2004). These reform initiatives have changed the internal power structure within the university. University managers and their staff are empowered in campus wide decision making; on the other hand, academics are losing their influence even on academic affairs in university wide decision making (e.g., Lyons and Ingersoll 2010).

In addition, the managerial reforms require academics to do more paper-works, increase their teaching hours, and undertake more entrepreneurial activities and community service to satisfy their managers and external stakeholders (Anderson 2008; Reed 2002). As results, academics' workloads are increasing in many countries, especially under strong managerial reforms (Bryson 2004; Lyons and Ingersoll 2010). Their increased workload has negatively impacted the balance between their work-life and personal life and academics spend most of their weekends dealing with their increased workloads (Barnett 2008; Tytherleigh et al. 2005). In addition, their job security is declining under the managerial reforms that pursue efficiency and budget cuts. For example, academics under this form of managerialism are fragmented as the university hires part time rather than full time academics, and provides contract based employment rather than tenured positions (Bentley et al. 2013; El-Khawas 2008). The lack of job security is the main source of jobs stress in the UK (e.g., Tytherleigh et al. 2005) and Australia (e.g., Gillespie et al. 2001).

Academic work environments are deteriorating in those countries with strong managerial reforms and most of them are in Anglo-Saxon countries (e.g., Hood 1995). The managerial reforms are designed to reduce public resources and replace public service by private or semiprivate providers through market competition (Amaral 2008; Anderson 2008; Gillespie et al. 2001). Because of the basic motivation of the new public management, the new public management accompanies budget cuts in higher education, especially in terms of per pupil measure (e.g., Fredman and Doughney 2012; Parker and Jary 1995). Reflecting this fact, a nationwide study on academic work conditions has been conducted mainly in the countries with strong new public management systems-e.g. UK, Australia, New Zealand, etc. (e.g., Fredman and Doughney 2012; Houston et al. 2006; Tytherleigh et al. 2005). These studies consistently report that academics' job satisfaction is declining and job stress is increasing in these countries.

\section{Method}

Data

This study uses data from the international comparative survey of the CAP of 2007-2008, which includes 19 higher education systems. The questionnaire covers job satisfaction and job stress as well as academics' demographics, career development, perceptions of scholarship, workload, work environment, and governance and management. All participating 
countries used the same survey questions and the data were collected from institutions granting degrees for four or more years. The data were collected from 800 or more cases in each country and an international methodology team checked coding and variables (for details, see Teichler et al. 2013). We selected only the university sector and excluded nonuniversity sectors (e.g., polytechnic, research institution) for comparisons across systems.

In addition, we excluded part time academics, or research only (or teaching only) academics because part time academics have different patterns of academic works compared to full time academics (e.g., Kinman and Jones 2008) and job satisfaction and job stress differ by their major function of teaching and research (e.g., Bryson 2004; Thorsen 1996). Latin American countries (Mexico, Brazil, and Argentina) have a relatively large share of part-time academics represented in the data, whereas European countries have a relatively large share of research only academics. This will improve comparability between countries because each country collected their data from different populations, e.g., some countries include part-timers and other countries full-timers only; some countries include research only faculty while others include faculty with teaching and research function.

\section{Analytical methods}

This study applies two analytical methods corresponding to the purposes of the study. We classify the 19 higher education systems that participated in the CAP survey by job satisfaction and job stress. The classification provides insight on how each country differs from other countries in terms of job satisfaction and job stress. Then one representative country from each type is chosen as a case to examine whether managerial reform as measured by the extent of performance-based management, have impacts on job satisfaction and job stress in these selected countries.

For the classification of higher education, this study applies k-means classification to classify the 19 higher education systems into one of four categories by their job satisfaction and job stress. In this case, the unit of analysis is country level, which is the 19 countries. A k-means clustering is a method of cluster analysis that aims to partition $n$ observations into $k$ clusters and in which each observation belongs to the cluster with the nearest mean (Kanungo et al. 2002). Through the classification process, we classify 19 higher education systems into one of high satisfaction and high stress, low satisfaction and low stress, high satisfaction and low stress, and low satisfaction and high stress groups. We use the software of SPSS version 20 for the cluster analysis. In a subsequent analysis, this study tests whether the job satisfaction and job stress differ across the four groups by the multivariate analysis of variance. In addition, a profiling analysis is conducted to analyze how each group differs from other groups.

To examine whether performance-based management has an impact on job satisfaction and job stress, this study applies OLS regression analysis across the four countries chosen from each category. For the analysis, we control for the other variables that have impacts on job satisfaction and job stress based on the literature. Although each study included different variables based on their research purposes, many studies modeled some intrinsic and extrinsic factors as major predictors of job satisfaction and job stress (e.g., Ambrose et al. 2005; Jacobs and Winslow 2004; Olsen 1993; Rosser 2005; Seifert and Umbach 2008; Volkwin and Parmley 2000; Zhou and Volkwein 2004). According to the literature, academic freedom, shared governance, and faculty empowerment are critical intrinsic factors for their job satisfaction and job stress. In addition, some extrinsic factors such as salary, work conditions, workloads, and a feeling of affiliation are included in their analytical model for job satisfaction and job stress. As discussed, recent studies include the both intrinsic and extrinsic factors in explaining job satisfaction and job stress. Based on 
the literature review, this study includes these seven factors as control variable in modeling for testing the association between the performance-based management and job satisfaction/job stress. The functional form is represented below:

Job satisfaction $/$ job stress $=f[$ academic freedom, shared governance, empowerment, salary, work conditions, workload, feeling of affiliation) + NPM]

Variables and measures

In this study, the job satisfaction of academics is defined by 'overall' job satisfaction which is measured by the question "How would you rate your overall satisfaction with your current job?" Job stress is measured by the reaction to the following statement: "My job is a source of considerable personal strain." There are two ways of measuring job satisfaction and job stress-one is single item by the "general" job satisfaction or jobs stress and the other way is to measure by multiple items. Between the two methods, we measured job satisfaction and job stress by the single item measure because single measures provide simple feature of job satisfaction and job stress across countries. Studies on job satisfaction within a country prefer to use multiple items (e.g., Houston et al. 2006; Kinman and Jones 2008), but a single item is recommended in international comparative studies as Osagbemi (1999) has discussed in his measurement study on satisfaction. Job-satisfaction and job-stress items are measured on a five-point Likert scale ranging from "1" (very satisfied or very stressful) through "3" (neutral) to "5" (very dissatisfied or never stressful). The scaling method is the same or similar to many other job satisfaction and job stress studies (e.g., Bentley et al. 2013; Fredman and Doughney 2012; Tytherleigh et al. 2005). In the analyses, the scoring is reversed for ease of interpretation. A high scale score indicates high satisfaction or high stress.

For each variable, faculty members are asked to indicate on a five-point scale their perceptions of their academic freedom, shared governance, and empowerment at their employing institution. The measures of these variables are the same or similar to other studies (e.g., Bentley et al. 2013; Shin and Cummings 2010) that used the CAP data because both surveys are based on a comprehensive literature review in higher education research (Boyer et al. 1994; Teichler et al. 2013). The responses are coded from $1=$ strongly disagree to $5=$ strongly agree. Scholarly productivity is measured by each academic's self-reported number of articles published in refereed journals during the previous 3 years (2004-2006). Salary is measured by averaging the total annual income based on self-report and is transformed into a log variable in order to adjust for skewed distribution. Workload is measured by the average total working hours in a week and is transformed into a $\log$ variable. Faculty members are asked to indicate on a five-point ordinal scale on their perceptions of working conditions and affiliation with their employing institution. The responses are coded from $1=$ strongly disagree to $5=$ strongly agree. Details of survey questions and measures are reported in Table 1.

\section{Findings}

Typology of job satisfaction and job stress

According to the descriptive data, academics' job satisfaction is the highest in Mexico $(87 \%)$ and the lowest in the UK $(47 \%)$. There is almost twice the difference between the 
highest and lowest country. Job stress also varies across higher education systems from the highest of $68 \%$ (Korea) to the lowest of $20 \%$ (Malaysia). The extreme differences between systems may be related to various factors such as pressure for publication, salary, empowerment, academic freedom, governance, work conditions, workloads, and a feeling of affiliation. One group of countries show high satisfaction and high stress, a second group shows low satisfaction and low stress, and the third and fourth groups show high satisfaction and low stress or vice versa. For the classification of higher education systems, we applied k-means cluster analysis to provide better statistical evidence. According to the analysis, the four systems are classified into one of four categories as shown in Table 2.

The number of countries in each type is not equally distributed because the classification is based on closeness or differences between objects. The findings are interesting because most developing systems (South Africa, Mexico, Brazil, Argentina, and Malaysia) are in the low stress categories, either type A or C. In contrast, many of recently developed systems such as the Canada, Australia, Netherlands, Finland, Korea, and Hong Kong are in the high stress categories either type B or D. We tested whether the four types differ in job satisfaction and job stress using multivariate analysis of variance, and the test results supported our assumption that the four groups are significantly different in their job satisfaction and job stress (for job satisfaction, $F=244.074, p<.001$, and for job stress, $F=700.919, p<.001)$.

- The type A consists of developing (South Africa and Portugal) and the most developed systems (US). South Africa and Portugal are relatively less developed and the US is the most competitive higher education system.

- The type B is an interesting case. The academics in the countries in this category (Japan, Canada, Netherlands, Finland, and Korea) are highly satisfied and highly stressed at the same time. On the one hand, these countries provide well established work conditions based on their economic growth but, on the other hand these countries have also aggressively adopted performance-based management systems in the global competition (Locke et al. 2011).

- Type C includes the countries that have strong teaching-oriented systems (Mexico, Brazil, Argentina, and Malaysia) or research-oriented systems (Italy and Norway). According to Cummings and Shin (2013), most Latin American countries are in teaching focused systems, while European countries are in research-focused systems.

- Type D is the countries that have strong performance-based managerial systems (UK, Australia, and Hong Kong) (Hood 1995; Locke et al. 2011) or very transformative countries (Germany and China). Academics in Germany are experiencing dramatic changes, especially in the former East Germany (Teichler 2011). China also emphasizes faculty performance while academic freedom and shared governance are not in place (Wang and $\mathrm{Fu} 2009$ ).

We analyzed how the four types differ. For the profiling analysis, we chose the variables that have close association with job satisfaction and job stress based on our literature review. We examined the profiles of the four categories by academic freedom, shared governance, faculty empowerment, salary, work conditions, workloads, and management styles. In addition, we included research productivity of academics as a measure of academic performance. The descriptive data are presented in Table 3.

As expected, the systems in the high satisfaction category (type B or type C) show a relatively high score on intrinsic factors (academic freedom and shared governance), but show inconsistent patterns on extrinsic factors. On the other hand, the systems in high stress (type B or type D) show higher scores on extrinsic factors, but inconsistent patterns 
Table 1 Variables and measures

\begin{tabular}{|c|c|c|}
\hline Variables & Questionnaire items & Measurement \\
\hline \multicolumn{3}{|l|}{ Dependent variable } \\
\hline Job satisfaction & $\begin{array}{l}\text { How would you rate your overall satisfaction with your } \\
\text { current job? }\end{array}$ & 5 Point Likert scale \\
\hline Job stress & My job is a source of considerable personal strain & 5 Point Likert scale \\
\hline \multicolumn{3}{|l|}{$\begin{array}{l}\text { Independent } \\
\text { variable }\end{array}$} \\
\hline Academic Freedom & The administration supports academic freedom & 5 Point Likert scale \\
\hline Shared governance & $\begin{array}{l}\text { At my institution, there is a collegiality in decision-making } \\
\text { processes. At my institution, there is a good } \\
\text { communication between management and academics }\end{array}$ & $\begin{array}{l}\text { Mean of } 2 \text { items }(5 \\
\text { point Likert scale) }\end{array}$ \\
\hline Empowerment & $\begin{array}{l}\text { How influential are you in helping to shape key academic } \\
\text { policies? (Department level, Faculty level, Institutional } \\
\text { level) }\end{array}$ & $\begin{array}{l}\text { Mean of } 3 \text { items ( } 5 \\
\text { point ordinal scale) }\end{array}$ \\
\hline Salary & Overall annual gross income (including supplements) & $\begin{array}{l}\text { Continuous } \\
\quad \text { (transformed } \log \text { ) }\end{array}$ \\
\hline Working condition & Classrooms, Library facilities, Office, Secretarial support & $\begin{array}{l}\text { Mean of } 4 \text { items }(5 \\
\text { point Likert scale) }\end{array}$ \\
\hline $\begin{array}{l}\text { Technology } \\
\text { support }\end{array}$ & $\begin{array}{l}\text { Technology for teaching, Computer facilities, } \\
\text { Telecommunications }\end{array}$ & $\begin{array}{l}\text { Mean of } 3 \text { items ( } 5 \\
\text { point Likert scale) }\end{array}$ \\
\hline Research support & $\begin{array}{l}\text { Laboratories, Research equipment and instruments, } \\
\text { Research support staff, Research funding }\end{array}$ & $\begin{array}{l}\text { Mean of } 4 \text { items ( } 5 \\
\text { point Likert scale) }\end{array}$ \\
\hline Workload & $\begin{array}{l}\text { Weekly working hours (Teaching, Research, Service, and } \\
\text { Administration) }\end{array}$ & $\begin{array}{l}\text { Continuous } \\
\text { (Transformed log) }\end{array}$ \\
\hline Affiliation & $\begin{array}{l}\text { The degree to which each of the following affiliations is } \\
\text { important to you (Academic discipline, Department, } \\
\text { Institution level) }\end{array}$ & $\begin{array}{l}\text { Mean of } 3 \text { items }(5 \\
\text { point ordinal scale) }\end{array}$ \\
\hline $\begin{array}{l}\text { Performance } \\
\text { oriented } \\
\text { management }\end{array}$ & $\begin{array}{l}\text { At my institution, there is a strong } \\
\text { performance orientation }\end{array}$ & 5 point Likert scale \\
\hline
\end{tabular}

Table 2 Typology of job satisfaction and job stress

\begin{tabular}{|c|c|c|c|}
\hline & & \multicolumn{2}{|l|}{ Job satisfaction } \\
\hline & & High & Low \\
\hline \multirow[t]{2}{*}{ Job stress } & High & Japan, Canada, Netherlands, Finland, Korea & $\begin{array}{l}\text { UK, Australia, Germany, China, Hong } \\
\text { Kong China }\end{array}$ \\
\hline & Low & $\begin{array}{l}\text { Italy, Norway, Mexico, Brazil, Argentina, } \\
\text { Malaysia }\end{array}$ & USA, Portugal, South Africa \\
\hline
\end{tabular}

on intrinsic factors. These findings imply that job satisfaction is relatively highly associated with intrinsic factors while job stress is associated with extrinsic factors. As well as the intrinsic and extrinsic factors, the typology is associated with institutional management and their academic productivity. For example, the higher education systems with high stress (type B or type D) demonstrate a higher performance-based management style than the 
systems with low stress (type A or type C). These systems show a relatively higher rate of academic productivity as measured by published articles.

\section{Regression analysis}

We conducted an OLS regression analysis to test whether the performance-based management affects job satisfaction and job stress across the four types controlling for other factors. In the model, we selected the US from type A, Korea from type B, Italy from type $\mathrm{C}$, and the UK from type D. We selected these countries because they show the highest mean score of job satisfaction or job stress in each group. The selection of an extreme case in each group may overestimate the specific dimensions of job satisfaction and job stress, but this will show clear distinctions between countries which are represented as four types in this study. The unit of analysis is individual academics who are included in the data. For the analysis, we included the performance-based management as well as the determinants of job satisfaction and job stress to test whether the performance-based management affects job satisfaction and job stress.

Table 4 shows the regression-analysis results across four countries. According to the analysis, intrinsic factors such as academic freedom, shared governance, and empowerment are significant in explaining job satisfaction in some countries, e.g., academic freedom in the US and Italy, shared governance in Korea and the UK, and empowerment in Italy and the UK. Some extrinsic factors are significant in explaining job satisfaction, e.g., research support and the feeling of affiliation across the four countries, and salary in Korea, work conditions in Italy, and Technology support in Korea and the UK. None of the four countries shows clear distinctions between intrinsic or extrinsic factors. The findings suggest that both intrinsic and extrinsic factors are associated with job satisfaction at the same time, as we discussed in our literature review. The model for job stress is statistically significant though the total variance explained is quite low in Korea and Italy as shown in Table 4. Although the interpretation and generalizability are limited, the findings from the analysis have implications for a follow up study. Similar to job satisfaction, some intrinsic and extrinsic factors are simultaneously associated with job stress. All the significant intrinsic factors have a negative association with job stress.

One of our research interests lies in whether the performance-based management affects job satisfaction and job stress. The performance-based management is not associated with job satisfaction, but with job stress. Academics in Korea and the UK feel stressed with the performance-based management. Although the performance-based management comes with deregulation, it evaluates faculty performance by predetermined indicators and tends to link the performance with budget allocation (e.g., Shin 2010). As a result, academics feel stressed with performance-based management.

\section{Discussion}

Our classification showed that the academics with high job satisfactions are in the European countries or Latin American countries. Academics in the European countries are research focused, they hold relatively high faculty power as discussed by Clark's (1983) coordination model, and they are highly respected in their society (Ben-David 1977). Both Japan and Korea have a strong European tradition of higher education although they were strongly influenced by the USA after World War II (e.g., Altbach 1989). Interestingly, academics are highly satisfied with their position in Latin American countries where 
Table 3 Profiles of four types

\begin{tabular}{lcclc}
\hline & $\begin{array}{l}\text { Type A (low } \\
\text { satisfaction/ } \\
\text { low stress) }\end{array}$ & $\begin{array}{l}\text { Type B } \\
\text { (high-satisfaction/ } \\
\text { high stress) }\end{array}$ & $\begin{array}{l}\text { Type C (high } \\
\text { satisfaction/ } \\
\text { low stress) }\end{array}$ & $\begin{array}{l}\text { Type D } \\
\text { (low-satisfaction/ } \\
\text { high stress) }\end{array}$ \\
\hline Job satisfaction (\%) & 52.2 & 69.6 & 69.5 & 55.3 \\
Job stress (\%) & 35.9 & 51.8 & 27.4 & 47.0 \\
Academic freedom & 41.9 & 48.2 & 52.6 & 45.8 \\
Shared governance & 26.6 & 29.1 & 42.5 & 25.4 \\
Empowerment & 36.1 & 33.2 & 41.4 & 28.6 \\
Salary & $61,729.0$ & $71,110.6$ & $31,657.0$ & $64,979.2$ \\
Workload (hours) & 44.8 & 48.7 & 42.4 & 47.3 \\
Performance-based & 44.5 & 58.8 & 41.5 & 68.4 \\
$\quad$ management & & 8.0 & 6.0 & 8.7 \\
Research productivity & 4.9 & & & \\
\hline
\end{tabular}

(1) Job satisfaction and job stress (\%) are the average proportion from countries in each typology. (2) Percentage (\%): 'strongly agree' and 'agree' in five Likert scales. (3) Average from countries in each typology. (4) Academic freedom, shared governance, empowerment, performance-based management: percentage (\%) of 'strongly agree' and 'agree' in five Likert scales. (5) Salary: total income per year. (6) Workload: weekly hours for teaching, research, service, administration, and others. (7) Research productivity: number of articles in last 3 years

academics have a relatively stronger preference for teaching and also they spend most of their time on teaching activities (e.g., Teichler et al. 2013). The high satisfaction of Latin American academics might be related to the fact that academics feel happy with their job when they teach students as discussed by Boyer (1990) and O’Meara and Rice (2005).

In addition, Olsen and Near (1994) and Winer and Sarros (2002) found that job satisfaction is high when their job is clearly defined. Their finding suggests that academic job satisfaction is high when a country emphasizes either teaching or research. In the same line, this study also found that academics in the balanced systems have low job satisfaction compared to those in teaching focused (Latin America) or research focused systems (Europe). As Shin (2011) and Locke and Bennion (2013) have discussed, academics feel more stressful and their job satisfaction is declined when the university began to emphasize the research function in the global competition in addition to quality of teaching. However, faculty role differentiation does not wholly explain job satisfaction in the European countries and Latin American countries. In-depth discussion is needed to explain high job satisfaction in the research focused European systems because academics feel stressed with their research while they feel less so with their teaching (e.g., Hendel and Horn 2008; Thorsen 1996).

The high job satisfaction in the European countries is related to the social systems in continental Europe when the modern university emerged. As described by Ben-David (1977), academics were considered to be the top talent in society when the modern university emerged in Germany and related higher education systems. They are expected to contribute to their society by discovering new knowledge, and train the next generation intellectuals; so they are highly regarded in their society, their academic freedom is guaranteed, and their power on the campus is considerable. Therefore, their job satisfaction is high compared to their colleagues in Anglo-American countries although their jobmainly research-accompanies high stress. Among the European countries, Germany is an exceptional case. Höhle and Teichler (2013) state that the German academics' job 


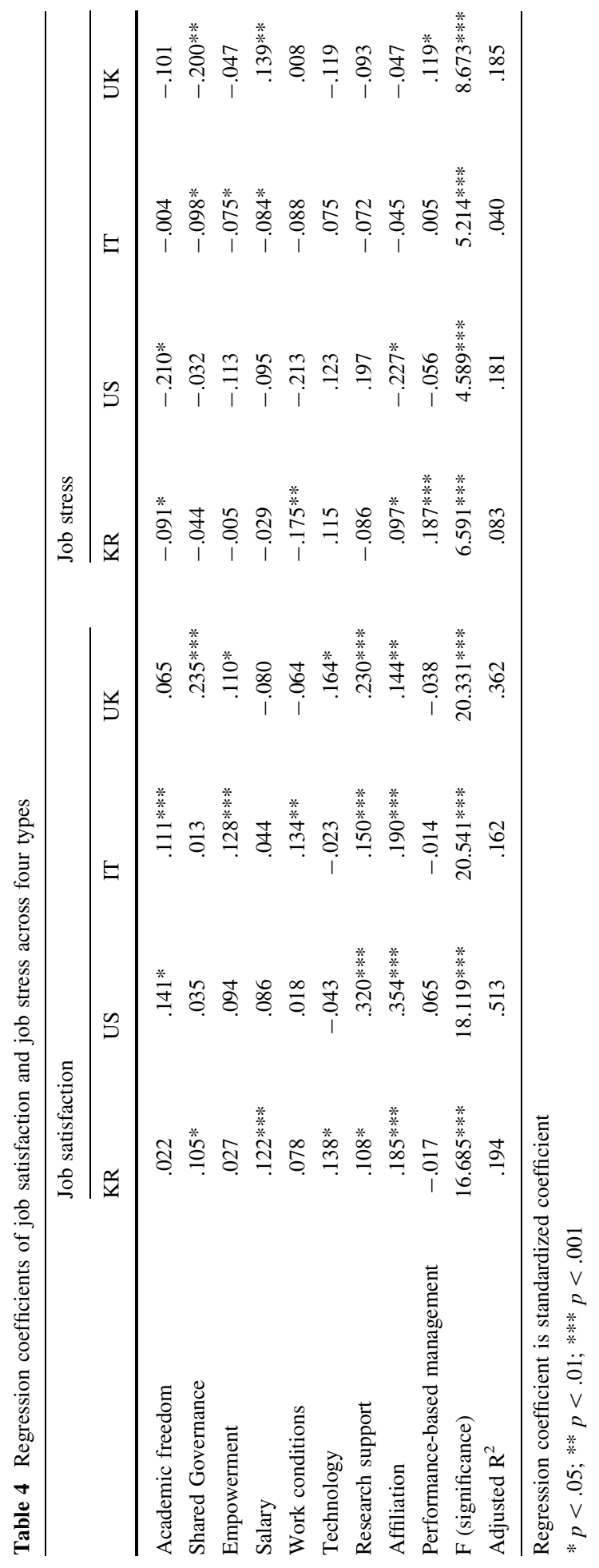


satisfaction is not low in their international comparison, but the overall job satisfaction of German academics is ranked $9^{\text {th }}$ place among the 12 countries included in Bentley et al. (2013). We discuss this later in this section.

In addition, this study found that Anglo-American countries and the countries with strong managerial reforms are in the high job stress category. The Anglo-American countries fall in the category of market coordination in Clark's (1983) model where the market principle is deeply embedded in decision-making processes in these countries. Academics enjoy relatively less autonomy than their peers in the European countries. In addition, most of the Anglo-American countries emphasize a balance between teaching and research, so that academics feel stressed while the other systems emphasize either teaching or research (Cummings and Shin 2013). Most academics are not efficient both in teaching and research (e.g., Shin 2011). Further, these systems have adopted strong managerial reforms, so that work conditions are less satisfactory than other systems. Locke and Bennion (2013) describe academic work conditions in the UK thus: "...their work industrialized, and their autonomy eroded, and they have been deskilled (p. 223)." Although the forms of managerial reforms differ across countries, the rapidly changing work environments lead to academic stress.

Our regression analysis also showed that the performance-based management is a significant factor in explaining job stress in Korea and the UK where strong management reforms are in place. The new public management was not significant in explaining job stress in the US or Italy which is classified as low job stress groups. Actually, the new public management in both US and Italy is relatively less emphasized than the UK, Australia, or Canada according to Hood (1995). Interestingly, the new public management is not significant in explaining job satisfaction in any of the four countries selected in the analysis. These findings suggest that managerial reforms do not affect job satisfaction, but impact job stress. The findings are similar to many other studies that found job satisfaction is more related to intrinsic factors rather than extrinsic factors although both factors affect job satisfaction or job stress (e.g., Houston et al. 2006). For this reason, among the systems with high job satisfaction, the countries with strong managerial reforms are in the high satisfaction and high stress category.

Another concern is the high satisfaction and high stress group. Based on Herzberg et al.'s (1959) theory, one may assume that job satisfaction is affected by intrinsic factors while job stress by extrinsic factors, so that both are coexisting simultaneously. However, this interpretation is not supported by much of the current literature that job satisfaction and job stress are determined by both intrinsic and extrinsic factors as discussed in literature review. In our regression analysis, both intrinsic and extrinsic factors are statistically significant in explaining job satisfaction and job stress in Korea which is the representative case of the high satisfaction and high stress. This is the same in the US and the UK. Again, this study supports many other studies that found job satisfaction and job stress are determined by both intrinsic and extrinsic factors (e.g., Bryson 2004; Parker and Jary 1995). Our remaining discussion point is how high job satisfaction and high job stress occur at the same time in these countries. Some in-depth discussions provide implications for the interpretation of this finding.

The high job satisfaction in the European countries and the two East Asian countries (Japan and Korea) could be explained in terms of their high social status within their society and high academic freedom in their university. Although these factors differ slightly across countries, academics are well regarded and their job is respected in society. As in the European countries, scholars are highly regarded in their society from the Confucian tradition both in Japan and Korea (e.g., Shin 2012). Scholars are the respected intellectuals of the Confucian society, they are role models for other people, and they are 
the leaders in community. As well as the academics in European and the two East Asian countries, Canadian academics are highly satisfied with their job-about $74 \%$ of the academics are satisfied with their job (e.g., Weinrb et al. 2013). Weinrb et al. (2013) explain the high job satisfaction in terms of the powerful role of faculty unions, well protected work conditions for full-time academics, and the collegiality of academics in the decision making process.

Academic jobs have become stressful when their governments have implemented managerial reforms. The five countries in the category also adopted aggressive managerial reforms over the last 10 years. A sign of managerial reforms in these countries is governance reforms. In these countries, the legal status of the university was as a government organization, so that the government was in charge of securing required resources. However, these countries have aggressively adopted private forms of governance structure since the mid-1990s, e.g., the Netherlands in 1997, Japan in 2004, Finland in 2010, and Korea in 2012, respectively. Now, universities are in charge of securing their own budgets through generating external funding. Although the government reforms in Korea and Finland were adopted shortly before the CAP data was collected in 2007/2008, the policy discussions had been held for a long time in these countries and some other managerial reforms (e.g., funding and evaluation policy) were in place in these countries earlier than the governance reforms (e.g., Locke et al. 2011).

This discussion now considers the future of the high satisfaction and high stress group. Although they are in "high satisfaction" either in relation to their high social reputation (Netherlands, Finland, Japan, and Korea) or because they are protected by strong unions and collegiality (Canada case), their satisfaction may not be sustainable much longer given the strong managerial reform initiatives. This implies that job satisfaction in these countries may noticeably decline in the near future, and these countries might move to the low satisfaction and high stress group where Anglo-American countries are classified if the market oriented managerial reforms continue. Germany is a case of declining job satisfaction with high stress. It is not clear whether German academics are experiencing worse conditions than their colleagues in other European countries, but they are dealing with large size classes, and their working conditions are being forced to cope with strong social demands for mass higher education (Teichler 2013). Further, they have been competing for excellence initiatives since the mid-2000s (Kehm 2013). The recent trends of market-oriented reforms may not change in the short term, and their job satisfaction and job stress may be similar across countries in the globalized academia as Meyer et al. (2007) have discussed.

Academics' response to the managerial reforms differ by gender, seniority, employment status, major academic activities between teaching and research, affiliated disciplines, and individual performance (e.g., Bentley et al. 2013; Enders and Teichler 1997). One interesting finding from the CAP study is that senior academics are more satisfied and less stressed with their current job while juniors are the reverse (Bentley et al. 2013). This fact suggests that the managerial reforms are designed by seniors and administrated mainly to juniors. Tenured and full professors who hold stronger negotiating power set the new rules for juniors as discussed by Shin and Jang (2013). Because of that, it is a topic worthy of a follow up study using the same survey items.

\section{Conclusion}

Enders and Teichler (1997) concluded in their study of the academic profession in Europe, that "...the relatively independent nature of their (academics) jobs allows most academics 
to find areas of professional activity which are the source of professional attachment and satisfaction" (p. 347). However, this is changing now. The market-oriented managerial reforms mean that academics, especially in the Anglo-American universities, are experiencing declining job security, and lower salaries compared to other professional jobs in their country. The academic profession plays a critical role in the knowledge society; however, paradoxically their social status is simultaneously being devalued by financial constraints and pressure for accountability (Bentley et al. 2013; Enders and Teichler 1997). Academic jobs are increasingly insecure, more accountable, more entrepreneurial, and less well paid while also losing autonomy, power, and social reputation (e.g., Locke et al. 2011).

Policymakers and institutional leaders tend to believe that the managerial reforms contribute to the efficiency of university management and the quality of teaching and research. However, the 'cult' of managerial reforms is not supported by empirical research (e.g., Dunleavy et al. 2005; Gow and Dufour 2000; Hood and Peters 2004). According to Shin (2010), institutional performance is not higher in those US states with a form of performance-based accountability than the states without it. Some scholars (e.g., Waitere et al. 2011) also argue that the managerial reforms are cost inefficient because the managerial reforms result in costs for new administration processes, hiring new staff, and to rectify the problems caused by poor decisions. For example, college tuitions are rapidly increasing in those countries where there have been managerial reforms (e.g., Johnstone and Marcucci 2011). The high tuition rate might be caused by the managerial reforms as well as the diminished government support although we need more empirical research to examine this (e.g., Ehrenburg 2002).

On the other hand, managerial reforms bring a breath of fresh air to the academic society which tends to be conservative in their culture, activity, and organizational forms. Without external pressures, academics do not change their culture, their patterns of activities, and their academic organizational forms. The CAP project provides empirical evidence on how academic culture, activities, and working conditions as well as job satisfaction and job stress are changing in the new academic environments-mainly under market-oriented managerial reforms. The follow up comparative study of CAP will provide further insight on academic job satisfaction and job stress, especially in terms of what is happening in the transforming systems - high satisfaction and high stress group -in the long run.

Open Access This article is distributed under the terms of the Creative Commons Attribution License which permits any use, distribution, and reproduction in any medium, provided the original author(s) and the source are credited.

\section{References}

Altbach, P. G. (1989). Twisted roots: Western impact on Asian higher education. Higher Education, 18, 9-29.

Amaral, A. (2008). Transforming higher education. In A. Amaral, I. Bleiklie, \& C. Musselin (Eds.), From governance to identity (pp. 81-94). Berlin: Springer.

Ambrose, S., Huston, T., \& Norman, M. (2005). A qualitative method for assessing faculty satisfaction. Research in Higher Education, 46(7), 803-830.

Anderson, G. (2008). Mapping academic resistance in the managerial university. Organization, 15(2), 251-270.

Barnett, R. (2008). Being an academic in a time-impoverished age. In A. Amaral, I. Bleiklie, \& C. Musselin (Eds.), From governance to identity (pp. 7-18). Berlin: Springer. 
Ben-David, J. (1977). Centers of learning: Britain, France, Germany and the United States. New York: McGraw-Hill.

Bentley, P. J., Coates, H., Dobson, I. R., Goedegebuure, L., \& Meek, V. L. (2013). Academic job satisfaction from an international comparative perspective: Factors associated with satisfaction across 12 countries. In P. J. Bentley, H. Coates, I. R. Dobson, L. Goedegebuure, \& V. L. Meek (Eds.), Job satisfaction around the academic world (pp. 239-262). Berlin: Springer.

Boyer, E. L. (1990). Scholarship reconsidered: Priorities of the professoriate. Princeton, NJ: Carnegie Foundation for the Advancement of Teaching.

Boyer, E. L., Altbach, P. G., \& Whitelaw, M. J. (1994). The academic profession: An international perspective. Carnegie Foundation for the Advancement of Teaching.

Bryson, C. (2004). What about the workers? The expansion of higher education and the transformation of academic work. Industrial Relations Journal, 35(1), 38-57.

Catano, V., Francis, L., Haines, T., Kirpalani, H., Shannon, H., Stringer, B., et al. (2010). Occupational stress in Canadian universities: A national survey. International Journal of Stress Management, 17(3), 232-258.

Clark, B. R. (1983). The higher education system: Academic organization in cross-national perspective. Berkeley, CA: University of California Press.

Cummings, W. K. (2004). The Institutions of education: A comparative study of educational development in the six core nations. Symposium Books: Oxford.

Cummings, W. K., \& Shin, J. C. (2013). Teaching and research in contemporary higher education: An overview. In J. Shin, A. Arimoto, W. K. Cummings, \& U. Teichler (Eds.), Teaching and research in contemporary higher education: Systems, activities, nexus, and rewards. (pp. 1-12). Dordrecht: Springer.

Dunleavy, P., Margetts, H., Bastow, S., \& Tinkler, J. (2005). New public management is dead-Long live digital-era governance. Journal of Public Administration Research and Theory, 16, 467-494.

Ehrenburg, R. G. (2002). Tuition rising: Why college costs so much. MA: Harvard University Press.

El-Khawas, E. (2008). Emerging academic identities: A new research and policy agenda. In A. Amaral, I. Bleiklie, \& C. Musselin (Eds.), From governance to identity (pp. 31-44). Berlin: Springer.

Enders, J., \& Teichler, U. (1997). A victim of their own success? Employment and working conditions of academic staff in comparative perspective. Higher Education, 34, 347-372.

Fredman, N., \& Doughney, J. (2012). Academic dissatisfaction, managerial change and neo-liberalism. Higher Education, 64, 41-58.

Gillespie, N. A., Walsh, M., Winefield, A. H., Dua, J., \& Stough, C. (2001). Occupational stress in universities: Staff perceptions of the causes, consequences and moderators of stress. Work and Stress, 15(1), 53-72.

Gow, J., \& Dufour, C. (2000). Is the new public management a paradigm? Does it matter? International Review of Administrative Sciences, 66(4), 573-597.

Halsey, A. (1992). Decline of Donnish Dominion. Oxford: Clarendon Press.

Harman, G. (2001). Academics and institutional differentiation in Australian higher education. Higher Education Policy, 14, 325-342.

Harman, G. (2003). Australian academics and prospective academics: Adjustment to a more commercial environment. Higher Education Management and Policy, 15(3), 105-122.

Hendel, D. D., \& Horn, A. S. (2008). The relationship between academic life conditions and perceived sources of faculty stress over time. Journal of Human Behavior in the Social Environment, 17(1/2), 61-88.

Herzberg, F., Mausner, B., \& Snyderman, B. B. (1959). The motivation to work. New York: Wiley.

Hill, M. D. (1986). A theoretical analysis of faculty job satisfaction/dissatisfaction. Educational Research Quarterly, 10(4), 36-44.

Höhle, E. A., \& Teichler, U. (2013). Determinants of academic job satisfaction in Germany. In P. J. Bentley, H. Coates, I. R. Dobson, L. Goedegebuure, \& V. L. Meek (Eds.), Job satisfaction around the academic world (pp. 125-144). Berlin: Springer.

Hood, C. (1995). The new public management in the 1980s: Variations on a theme. Accounting, Organizations and Society, 20(2/3), 93-109.

Hood, C., \& Peters, G. (2004). The middle aging of new public management: Into the age of paradox? Journal of Public Administration Research and Theory, 14(3), 267-282.

Houston, D., Meyer, L. H., \& Paewai, S. (2006). Academic staff workloads and job satisfaction: Expectations and values in academe. Journal of Higher Education Policy and Management, 28(1), 17-30.

Jacobs, J. A., \& Winslow, S. E. (2004). Overworked faculty: Job stresses and family demands. The ANNALS of the American Academy of Political and Social Science, 596(1), 104-129.

Johnstone, D. B., \& Marcucci, P. N. (2011). Financing higher education worldwide: Who pays? Who should pay?. Baltimore: The Johns Hopkins University Press. 
Kanungo, T., Mount, D. M., Netanyahu, N. S., Piatko, C. D., Silverman, R., \& Wu, A. Y. (2002). An efficient k-means clustering algorithm: Analysis and implementation. IEEE Transactions on Pattern Analysis and Machine Intelligence, 24, 881-892.

Kehm, B. M. (2013). To be of not to be? The impact of the excellence initiative on the german system of higher education. In J. C. Shin \& B. M. Kehm (Eds.), Institutionalization of world class universities in global competition (pp. 81-98). Berlin: Springer.

Kinman, G., \& Jones, F. (2008). A life beyond work? Job demands, work-life balance, and wellbing in UK academics. Journal of Human Behavior in the Social Environment, 17(1/2), 41-60.

Lacy, F. J., \& Sheehan, B. A. (1997). Job satisfaction among academic staff: An international perspective. Higher Education, 34, 305-322.

Locke, W., \& Bennion, A. (2013). Satisfaction in stages: The academic profession in the United Kingdom and the British commonwealth. In P. J. Bentley, H. Coates, I. R. Dobson, L. Goedegebuure, \& V. L. Meek (Eds.), Job satisfaction around the academic world (pp. 223-238). Berlin: Springer.

Locke, W., Cummings, W. K., \& Fisher, D. (2011). Governance and management in higher education: The perspective of the academy. Berlin: Springer.

Lyons, M., \& Ingersoll, L. (2010). Regulated autonomy or autonomous regulation? Collective bargaining and academic workloads in Australian universities. Journal of Higher Education Policy and Management, 32(2), 137-148.

McInnes, C. (2000). Changing academic work roles: The everyday realities challenging quality teaching. Quality in Higher Education, 6(2), 143-152.

Meyer, J. W., Ramirez, F. O., Frank, D. J., \& Schofer, E. (2007). Higher education as an institution. In P. J. Gumport (Ed.), Sociology of higher education: Contributions and their contexts (pp. 187-221). Baltimore: Johns Hopkins University Press.

O'Meara, K. A., \& Rice, R. E. (2005). Faculty priorities reconsidered: Rewarding multiple forms of scholarship. San Francisco: Jossey-Bass.

Olsen, D. (1993). Work satisfaction and stress in the first and third year of academic appointment. Journal of Higher Education, 64(4), 453-471.

Olsen, D., Maple, S. A., \& Stage, F. K. (1995). Women and minority faculty job satisfaction: Professional role interests, professional satisfactions, and institutional fit. Journal of Higher Education, 66(3), 267-293.

Olsen, D., \& Near, J. (1994). Role conflict and faculty life satisfaction. The Review of Higher Education, $17(2), 179-195$.

Osagbemi, T. (1999). Overall job satisfaction: How good are single versus multiply-item measures? Journal of Managerial Psychology, 14(5), 388-403.

Parker, M., \& Jary, D. (1995). The McUniversity-Organization, management and academic subjectivity. Organization, 2(2), 319-338.

Reed, M. (2002). New managerialism, professional power and organizational governance in UK universities: A review and assessment. In A. Amaral, G. Jones, \& B. Karseth (Eds.), Governing higher education: National perspectives on institutional governance (pp. 163-186). Dordrecht: Kluwer.

Romzek, B. S. (2000). Dynamics of public sector accountability in an era of reform. International Review of Administrative Sciences, 66, 21-44.

Rosser, V. J. (2005). Measuring the change in faculty perceptions over time: An examination of their worklife and satisfaction. Research in Higher Education, 46(1), 81-107.

Ryan, J. F., Healy, R., \& Sullivan, J. (2012). Oh, won't you stay? Predictors of faculty intent to leave a public research university. Higher Education, 63, 421-437.

Seifert, T. A., \& Umbach, P. D. (2008). The effects of faculty demographic characteristics and disciplinary context on dimensions of job satisfaction. Research in Higher Education, 49(4), 357-381.

Shin, J. C. (2010). Impacts of performance-based accountability on institutional performance in the US. Higher Education, 60(1), 47-68.

Shin, J. C. (2011). Teaching and research nexuses across faculty career stage, ability and affiliated discipline in a South Korean research university. Studies in Higher Education, 36(4), 485-503.

Shin, J. (2012). Higher education development in Korea: western university ideas, Confucian tradition, and economic development. Higher Education, 64(1), 59-72.

Shin, J. C., \& Cummings, W. K. (2010). Multilevel analysis of academic publishing across disciplines: Research preference, collaboration, and time on research. Scientometrics, 85(1), 581-594.

Shin, J. C., \& Jang, Y. S. (2013). World-class University in Korea: Proactive government, responsive university, and procrastinating academics. In J. C. Shin \& B. M. Kehm (Eds.), Institutionalization of world-class university in global competition (pp. 147-164). Berlin: Springer.

Taylor, M. (2012). Shared governance in the modern university. Higher Education Quarterly, 67(1), 80-94.

Teichler, U. (2007). Higher education systems. Sense Publishers: The Netherlands. 
Teichler, U. (2011). Germany: How changing governance and management affects the view and work of the academic profession. In W. Locke, W. K. Cummings, \& D. Fisher (Eds.), Changing governance and management in higher education: The perspectives of the academy. Berlin: Springer.

Teichler, U. (2013). Teaching and research in Germany: The notions of university professors. In J. Shin, A. Arimoto, W. K. Cummings, \& U. Teichler (Eds.), Teaching and research in contemporary higher education: Systems, activities, nexus, and rewards. (pp. 61-87). Dordrecht: Springer.

Teichler, U., Arimoto, A., \& Cummings, W. K. (2013). The changing academic profession: Major findings of a comparative survey. Berlin: Springer.

Thorsen, E. J. (1996). Stress in academe: What bothers professors? Higher Education, 31(4), 471-489.

Tytherleigh, M. Y., Webb, C., Cooper, C. L., \& Ricketts, C. (2005). Occupational stress in UK higher education institutions: A comparative study of all staff categories. Higher Education Research \& Development, 24(1), 41-61.

Volkwin, J. F., \& Parmley, K. (2000). Comparing administrative satisfaction in public and private universities. Research in Higher Education, 41(1), 95-116.

Waitere, H. J., Wright, J., Tremaine, M., Brown, S., \& Pausé, C. J. (2011). Choosing whether to resist or reinforce the new managerialism: The impact of performance based research funding on academic identity. Higher Education Research \& Development, 30(2), 205-217.

Wang, D., \& Fu, M. (2009). The evaluation of higher education expenditure performance and investment mechanism reform. International Education Studies, 2(1), 18-24.

Weinrb, J., Jones, G. A., Metcalfe, A. S., Fisher, D., Gingras, Y., Rubenson, K., et al. (2013). Canadian university academic's perceptions of job satisfaction: “... The future is not what it used to be". In P. J. Bentley, H. Coates, I. R. Dobson, L. Goedegebuure, \& V. L. Meek (Eds.), Job satisfaction around the academic world (pp. 83-102). Berlin: Springer.

Winefield, A. H., Gillespie, N., Stough, C., Dua, J., Haparachchi, J., \& Boyd, C. (2003). Occupational stress in Australian university staff: Results from a national survey. International Journal of Stress Management, 10(1), 51-63.

Winer, R., \& Sarros, J. (2002). The academic work environment in Australian universities: A motivating place to work? Higher Education Research and Development, 21(3), 241-258.

Zhou, Y., \& Volkwein, J. F. (2004). Examining the influence on faculty departure intentions: A comparison of tenured versus non-tenured faculty at research universities using NSOPF-99. Research in Higher Education, 45(2), 139-176. 